\title{
THE STUDY OF SUSTAINED COLONIALISM: AN EXAMPLE FROM THE KASHAYA POMO HOMELAND IN NORTHERN CALIFORNIA
}

\author{
Kent G. Lightfoot and Sara L. Gonzalez
}

\begin{abstract}
This article advocates for archaeological investigation of sustained colonialism that examines the implications of Native American negotiations with multiple waves of foreigners over the course of many decades, if not centuries. The study of native confrontations with successive groups of intruders, who often represented a diverse range of colonial programs and interests, involves analyses of not only indigenous encounters with first-wave colonists but also their entanglements with later colonists, particularly settler colonists. This will provide the necessary diachronic approach to consider the cumulative effects and implications of multiple colonial intrusions on specific tribes and how tribal negotiations with earlier colonial enterprises may have influenced and shaped their responses to later settler colonists. This article presents a case study of one such approach for the study of sustained colonialism that examines native entanglements with mercantile and settler colonists in northern California.
\end{abstract}

Este artículo aboga por una investigación arqueológica del colonialismo prolongado que examina las implicaciones de las negociaciones de grupos de indígenas norteamericanos con múltiples olas de extranjeros sobre el curso de muchas décadas, y hasta siglos. El estudio de las confrontaciones de los indígenas con grupos sucesivos de intrusos, quienes a menudo representaban una distribución diversa de programas e intereses coloniales, incluye no solo los análisis de los encuentros de los indígenas con los primeros colonos, sino también sus enredos con colonos posteriores, particularmente colonos pobladores. Esto proporcionará el enfoque diacrónico necesario para considerar los efectos e implicaciones acumulativos de múltiples intrusiones coloniales en tribus específicas, y las maneras en que las negociaciones tribales con empresas coloniales anteriores pudieron haber influenciado y formado sus reacciones hacia los colonos pobladores posteriores. Este artículo presenta un caso de estudio de tal enfoque para el estudio del colonialismo prolongado que examina los enredos de los indígenas con colonos mercantiles y pobladores en California del norte.

$\mathrm{T}$ The archaeology of colonialism in the Americas is undergoing a significant transformation. A previous generation of archaeologists focused research on native and European encounters in early colonial settings involving investigations of missions, fur trade outposts, and forts. Some scholars now advocate that we expand our investigations beyond indigenous interactions with these first-wave intruders to consider the full spectrum of colonialism, which includes later historical and contemporary contexts (Mitchell and Scheiber 2010; Rubertone 2012; Silliman 2009, 2012). A significant research domain that remains understudied in western North American archaeology is that of native entanglements-their social, political, and cultural relationships - with settler colonists from the United States in the nineteenth and twentieth centuries.

The purpose of this article is to promote the study of sustained colonialism. It employs a longterm perspective to examine how indigenous populations negotiated with multiple waves of foreigners who represented a diverse range of colonial programs and interests. We begin by discussing some of the challenges of implementing the archaeology of nineteenth-century and later historical indigenous places. We then

Kent G. Lightfoot $\square$ Department of Anthropology, Archaeological Research Facility, University of California, Berkeley, CA 94720-3710, USA (klightfoot@ berkeley.edu, corresponding author)

Sara L. Gonzalez $\square$ Department of Anthropology, University of Washington, Box 353100, Seattle, WA 98195-3100, USA (gonzalsa@uw.edu) 
outline why investigations of indigenous people that transcend precolonial, early colonial, and settler colonial periods are timely to contemporary archaeological research. Finally, we present a case study of the Kashaya Pomo Tribe's homeland in northern California that examines their entanglements with two different colonial programs over more than five decades, one implemented by Russian merchants and the other by settler colonists. The study highlights how the Kashaya Pomo's initial encounters with the Russian-American Company proved to be a time of learning and experimentation in negotiating with foreigners, a time that would in subsequent years provide crucial insights and cultural practices for surviving the onslaught of later settler colonists who entered their territory.

\section{Rethinking the Temporal Dimension of Colonialism}

Most Native American tribes tangled with multiple, successive colonial programs over the course of many decades, if not centuries. Successive waves of colonizers swept across North America, movements led by missionaries, merchants, soldiers, and settlers from Europe and later the United States. Each colonial enterprise employed a different suite of policies and practices for interacting with indigenous populations. Among the first intruders were traders from managerial or mercantile companies who moved rapidly into indigenous territories that contained terrestrial and maritime animals for the lucrative fur and hide trade. Other early intruders were Roman Catholic, Protestant, and Russian Orthodox missionaries, who founded outposts from which they attempted to Christianize and civilize indigenous populations. The first waves of colonization also included military troops dispatched by homeland countries to construct forts and military emplacements in order to protect their newly acquired territory from native incursions, as well as from seizures by competing European nations (Deagan 2010; Lightfoot et al. 2013:102-104; Nassaney 2015).

The expansion of settler colonies into indigenous territories was typically a later phenomenon in North America, particularly west of the Mississippi River. It involved the westward move- ment of colonists from Europe, and later the United States, who established permanent residences on native lands. The primary impetus for settler colonies was the land itself for building homesteads and farms. The founding of settler colonies unleashed a massive movement of foreigners into Indian territories, who typically attempted to displace and remove native peoples from their homelands, which were now coveted for occupation and settlement by incessant waves of interlopers (Johnston and Lawson 2000; Murray 2004). Consequently, settler colonists and their governments often employed a "logic of elimination" to remove natives from their lands through government treaties, violence, trespassing, and harassment (Lindsay 2012; Madley 2016; Russell 2001; Wolfe 2006). There is no arbitrary end date to settler colonialism in the United States, as native people continue to grapple today with a variety of political and economic forces that disenfranchise them from their lands (e.g., the federal recognition process that determines whose tribal histories are valid and whose are not).

\section{Beyond the Study of First Contact Encounters}

While archaeological investigations of the first wave of colonists and their encounters with native people are relatively common, there remains a significant gap in the study of indigenous entanglements with settler colonists. The focus of nineteenth- and twentieth-century archaeologies typically shifts to the colonists themselves (e.g., immigrant populations, imported laborers). This creates the impression that native peoples either disappeared or assimilated with the rise of the modern, pluralistic US nation. With the recent push to examine the full spectrum of colonialism, which includes nineteenth- and twentieth-century historical and contemporary contexts, a growing number of studies put indigenous people back on the central stage with settler colonists (e.g., Cipolla 2013; Mrozowski et al. 2009; Silliman 2009, 2012).

In undertaking archaeological investigations of US settler colonialism, several challenges should be acknowledged from the outset. One challenge concerns the detection and study of 
material remains produced by indigenous populations who continued to entangle with foreign interlopers entering their territories in the mid- to late nineteenth and the twentieth centuries. The strong linkages that exist between late precolonial and first contact archaeological manifestations typically become more tenuous and muted in later historical contexts (Lightfoot 2006; Silliman 2009). In initiating actions of persistence and survival in the face of the removal policies of settler colonists, native peoples were known to have been "hiding in plain site" (an intentional play on words) by downplaying outward and public displays of their community traditions and identities (Sleeper-Smith 2001). The detection of recent-aged Native American remains is further complicated by the continued use of persistent places on the landscape that have deep roots spanning back to precolonial times. As Schneider (2015) and others have documented, native peoples in historical times continued to use ancient indigenous sites that were vested with strong meanings and the memories of their ancestors.

A second challenge concerns the dating of late colonial indigenous sites. The reuse of ancient sites by indigenous peoples can create complex archaeological deposits in which later colonial-aged materials may not be readily recognized by archaeologists, particularly if native peoples were minimizing the use of EuroAmerican material objects by choice or because access to such goods became limited (Schneider 2015:704-705). Furthermore, as Liebmann (2012a) details for the American Southwest, more effort tends to be devoted to chronology construction in precolonial archaeological contexts than for historic-period indigenous places.

A third challenge is the most insidious-that is, how we define the temporal parameters of colonialism in North America. The transition from European colonization to that of the creation of the modern US nation remains relatively uncharted in many studies of indigenous peoples. In focusing on first-wave European colonists, there is strong precedent for archaeologists working in western North America to terminate their investigations of indigenous populations once American settlers later occupied their lands.
Some may question whether homestead allotments and movements of settlers into Indian lands promoted by the US government should be viewed as colonization per se. In its most basic definition, colonization is the movement of foreign peoples into indigenous homelands. Whether we view settlers supported by the United States as foreign colonists or not is a matter of debate. Yet there is little question that the actions of the American government were and are colonial in its policies and practices directed at native people. The United States continued to promulgate policies or "imperial effects" that kept indigenous groups at the bottom of the political hierarchy, limited their economic opportunities, and dispossessed them from their lands and ability to harvest traditional resources (Coronil 2007; Madley 2016:1; Stoler and McGranahan 2007). The term settler colonialism has thus been used by historians to highlight the structural elements of American colonialism and to emphasize that the settlement and dispossession of indigenous lands is not a singular episodic event but an ongoing process that native peoples continue to contend with to this day.

\section{The Study of Sustained Colonialism}

It is imperative that the archaeology of colonialism in North America expand its scope to include indigenous entanglements not only with first-wave colonists but with later invaders, particularly settler colonists during and after the takeover of Indian lands facilitated through the policies and practices of the United States. Without minimizing the challenges of discovering, recording, and dating late historical indigenous archaeological remains, we believe that a more concerted effort in the study of long-term, sustained colonialism will make considerable headway on all these fronts. In redirecting the archaeology of colonialism in this new direction, we will also need to continue our efforts to forge collaborations with tribal partners who share a common interest in better understanding the full consequences of colonialism in indigenous territories.

The ongoing legacy of colonialism is a real problem for many tribal people who are grappling with issues of federal recognition, 
repatriation of ancestral remains (e.g., the Native American Graves Protection and Repatriation Act), obtaining access to natural resources, maintaining a land base, and defending their legal rights and identities as Native Americans. Tribes must demonstrate continuous cultural and genealogical connections between themselves and previous generations of native peoples who supposedly disappeared in the difficult years of settler colonization. It is truly unfortunate that archaeologists have understudied how Indian peoples navigated and survived the later phases of colonization, since they were among the most brutal, destructive, and repressive times that many tribes experienced.

For example, in California the most perilous time to be an Indian was not during their encounters with Franciscan missionaries, Spanish and Mexican soldiers, or Russian businessmen. As difficult as these experiences were, confrontations with Euro-American settlers, beginning with the annexation of California by the United States in 1846, were far deadlier. Historians now refer to this violent and atrocious period in California-the Dark Age from 1846 to 1873 as an American genocide that was actively supported and funded by federal, state, and local governments, along with the vast majority of the citizenry and press. The unified goal of these settler colonists was to decimate Indian populations and to remove them from their lands (Lindsay 2012; Madley 2016). Analysis of archival documents (e.g., settler narratives, government accounts, censuses) shows how successful the combined forces of settler colonialism were in the mortality of California Indians. In 1846 there were approximately 150,000 native Californians. Fifty years later, in 1900, only 15,000 native Californians survived, with the other $90 \%$ of the population murdered or decimated by the ravages of disease and poverty (Lindsay 2012:336; see also Madley 2016:2).

The growing recognition of this American genocide is a double-edged sword. On one side, it acknowledges that the onslaught of settler colonialism in western North America was more horrific than any of the previous colonial programs. On the other side, it can play directly into terminal narratives or fatal impact models about the myth of the "vanishing Indian" due to cultural extinction, societal collapse, or the decimation of indigenous populations (Mitchell and Scheiber 2010:6; Panich 2013; Schneider 2015:708; Silliman 2012; Wilcox 2010). The underwhelming silence from the archaeological discipline about this phase of indigenous and US history is doing little to remedy the current situation. Although few archaeologists have engaged with survivance (Atalay 2006; Silliman 2012), we believe that it is a useful concept for situating such trauma within the larger frame of native lived experiences of colonialism.

Gerald Vizenor, an Anishinaabe scholar, defines survivance as a "narrative resistance to absence, literary tragedy, nihility, and victimry" (2008:19) that highlights the sustained creativity and agency that enabled native peoples not simply to passively survive but to actively flourish in the face of settler colonial violence. Contemporary scholarship on Native American genocide must clarify how indigenous populations persisted through strategic and creative actions to maintain their oral traditions and cultural practices and to ensure the survival of their communities and families. While the concepts of persistence (Panich 2013; Silliman 2009) and ethnogenesis (Cipolla 2013) in archaeology specifically call attention to the ways in which native peoples strategically navigated their social, material, and economic relations with colonists and settlers, survivance offers an explicitly indigenous framework for disrupting terminal settler colonial narratives that deny the active presence of indigenous populations today. Furthermore, by centering native experiences and connecting these experiences and histories to their current outcomes, stories of survivance focus attention on the contemporary struggle of tribal nations to navigate US settler colonialism.

Survivance provides a necessary research framework for situating the study of sustained colonialism, specifically, how native peoples devised cultural practices and negotiations in their confrontations with settler colonists. By examining the cumulative effects and implications of multiple colonial programs for specific tribes, we can evaluate how tribal negotiations with earlier colonial enterprises may have influenced and shaped their responses to later settler 
colonists. Tribal encounters with first-wave colonists served as a learning curve for experimenting with various responses to dealing with foreigners who trespassed on their lands. Tribal people would have drawn upon these earlier experiences, particularly those that had proved successful in mediating colonial intrusions, in developing tactical actions and cultural practices when confronted with later invasions by settler colonists. Thus, in understanding how native peoples survived the darkest years of settler colonialism, we believe that it is crucial to understand how they interacted with earlier colonists and how these experiences may have shaped later responses to and relations with settler colonists.

The upshot of this discussion is to highlight how histories of colonial entanglements would have varied greatly among tribal groups who confronted multiple, but often different, suites of foreigners and settlers encroaching into their lands. Tribal mediations were most certainly influenced by various factors, but an important consideration would have been their previous experiences in dealing with foreign intruders. Since tribal groups often confronted a different succession of colonial programs, even in the same regions, the actions and responses they employed may have diverged considerably over time. For example, indigenous groups along the coast of California interacted differentially with a diverse range of first-wave colonists, including Franciscan missionaries, Spanish/Mexican soldiers, Russian merchants, British fur traders, and Euro-American miners, before they confronted the full onslaught of settler colonists in the mid- to late nineteenth century. These complex histories of indigenous interactions with earlier colonial regimes helped shape the diverse range of engagements and relations they developed with later settler colonists, from the nineteenth century into the present (Lightfoot 2005: 210-233).

\section{The Study of Sustained Colonialism in the Kashaya Pomo Homeland}

The remainder of this article presents a case study of sustained colonialism that examines how the Kashaya Pomo people of northern
California maintained their cultural values and native community during their entanglements with two distinctive colonial ventures, from the early 1800 s to the 1860 s. The study highlights how tribal experiences and responses to firstwave colonists proved to be important factors in how the Kashaya used their cultural practices and other strategies to contend with the intrusion of settler colonists.

The first colonial invasion of the Kashaya homeland of Metini involved the RussianAmerican Company (RAC), which founded the Ross Colony as a commercial venture north of San Francisco Bay. From here, the company harvested sea mammal pelts, commenced agricultural production, and traded with the Franciscan missions of Spanish/Mexican California (Figure 1; Farris 2012; Lightfoot 2005). The RAC depended on the labor of native Alaskan hunters to procure sea otters and other lucrative sea mammals. It also conscripted Kashaya Pomo and other local native Californians as seasonal laborers who performed strenuous work involving agrarian and mercantile production, for which they were paid food, clothing, tobacco, glass beads, and other goods.

After struggling for many years to make its enterprise economically viable, the RAC sold its assets to John Sutter in 1841. The abandonment of the Metini region by the Russian merchants set the stage for the second wave of intrusions into Kashaya lands by Mexican and American settler colonists. Wilhelm Benitz, the most prominent of these early settlers, established a successful ranching operation on the foundations of the former Russian colony, where he and his family raised livestock and crops and maintained a commercial timber operation (Lightfoot et al. 1991:122; Tomlin 1993:6-10). Similar to the situation at Colony Ross, the principal laborers at the Benitz Ranch from the 1840 s to the 1860s were the Kashaya Pomo, as well as other local indigenous peoples, and a few Mexican vaqueros, who introduced the native community to Hispanic foods (flour tortillas), the Spanish language, and Catholicism (Kennedy 1955:7778; Oswalt 1964:4). Benitz provided his Indian laborers with a place to stay, protection, food, and wages in return for their labor (Kennedy 1955:76-79; Tomlin 1993:8). 


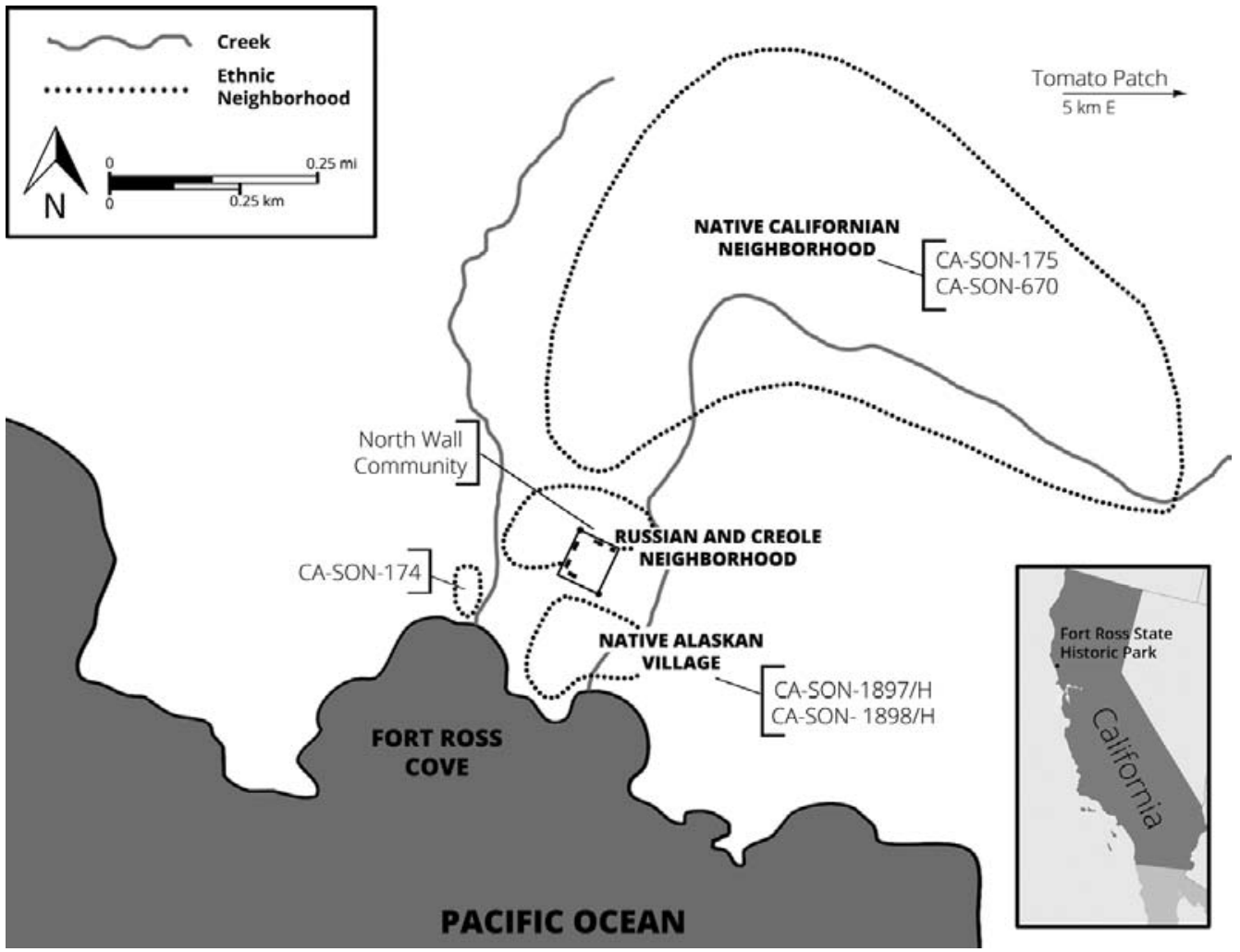

Figure 1. Map of the Kashaya homeland showing the Ross Colony and sites mentioned in the text.

\section{First Contact Encounters with the RAC (1812-1841)}

Our initial program of research employed a practice-based approach for examining the effects of first contact encounters at Colony Ross. Employing multiple lines of evidence (archaeological, ethnohistorical, native oral traditions), we examined changes in the subsistence practices, technology, and spatial organization that took place among indigenous populations during their encounters with first-wave colonists (Lightfoot et al. 1991; Lightfoot et al. 1997; Lightfoot et al. 1998). We found that local native people initiated diverse mediations with the mercantile colonists that enabled them to sustain an active Indian community with a distinctive Kashaya identity. The first finding was that they maintained many of their core cultural practices, which included the production and use of chipped-stone and ground-stone artifacts, bone tools, and shell beads and ornaments, as well as the gathering of large quantities of shellfish and hunting of terrestrial game. The ubiquitous presence of fire-cracked rocks of varying size indicates that they continued to employ conventional methods of cooking, which included underground ovens, hearths, and cooking gruel in watertight baskets using heated cooking stones (Lightfoot 2005:166-167).

New foods, including beef, mutton, and pork, were adopted by the Kashaya Pomo living and working near the Russian settlement of Ross. Yet Kashaya chefs butchered and cooked the new meats like any other large wild ungulates (Lightfoot 2005:168). The colonists introduced them to new material media, such as ceramics, glass, and metal. But again, the Kashaya used these materials in a distinctly "Indian" way, as raw materials for the construction of native artifact forms, including glass flake tools and projectile points, ceramic beads, pendants, gaming pieces, amulets, and fishhooks. The Kashaya also laid out and organized village space according to their 
principles, practices that transcended late precolonial and early colonial times. They continued to regularly clean the floors of house structures and to dump trash in nearby garbage dumps, often downslope of the residences (Lightfoot et al. 1991:116-119; Martinez 1998:133-135).

The second finding was that the Kashaya people who lived and worked at Colony Ross sustained close relationships with indigenous populations in the broader landscape. Some native women entered into relationships with colonist men, establishing interethnic residences, while other Kashaya families and individual adults served as seasonal agrarian workers living in separate indigenous villages north of the Ross Stockade. However, the Kashaya maintained strong connections between the colonial "front lines" and their homelands in the "forest depths" through frequent movement back and forth between these places depending on work schedules, souring relationships with colonist men, and the need to return home (Lightfoot 2005:170-171). Thus, the Kashaya continued to practice a settlement pattern that allowed them to maintain residences both near and far from the Ross Colony (Supplemental Texts 1 and 4).

The third finding was the creation of a broader tribal organization. Prior to the arrival of the Russians, the Kashaya Pomo people were divided into a series of small, autonomous polities based primarily on kin relationships, each of which supported a suite of political leaders, religious specialists, dancers, and healers (Lightfoot et al. 1991:43-119). The RAC worked closely with the indigenous leaders of these polities in contracting laborers to work at the colony and in maintaining discipline among the Indian workers. In contrast to the nearby Franciscan missionaries, the Russian merchants made no concerted effort to change the political structure of the Kashaya. However, a significant implication of these colonial relationships was the institutionalization of native political positions and an enhancement in the status, power, and clout of some leaders. This was particularly true for the toyon, the name the Russians gave to the leader designated as a primary spokesperson for the Kashaya people.

As Kennedy (1955:18-19) outlined, the consequences of this colonial action were a rise in the influence and recognition of the toyon as the leader of the Kashaya Pomo and the consolidation of formerly autonomous polities into a broader tribal organization. Demographic decline and the aggregation of people living and working together at the Ross settlement also facilitated the creation of a broader political entity representing the various Kashaya Pomo (Lightfoot 2005:237-238). What emerged by the early nineteenth century was a new, more inclusive political organization that proved to be a significant asset not only in maintaining Kashaya traditions and core values but also in providing a broader population base for responding to and buffering the impacts of colonialism.

\section{Kashaya Entanglements with Settler Colonists (1840s-1860s)}

Our investigation of settler colonialism in the Kashaya homeland involved a more inclusive search to detect and date later indigenous archaeological remains that were associated with the later settler colonial period. This included new collaborative fieldwork with the tribe and refined chronologies of historical materials such as glass beads. We identified two sites, Metini Village (CA-SON-175) and CA-SON-174, as Kashaya villages associated with the Benitz Ranch (see Supplemental Texts 2 and 4).

Our approach for the study of sustained colonialism involved the selection of a series of indigenous sites that provided multiple temporal points across a time line for examining culture change and persistence that spanned late precolonial, mercantile colonial, and settler colonial times in the homeland of the Kashaya Pomo. For each site chosen, we examined the same four dimensions (e.g., technology, menu/food processing, dress, and settlement layout) to evaluate the degree to which the technological, social, and ritual practices of the Kashaya transformed during their initial encounters with the RAC and then later in their engagements with settler colonists. The six sites chosen for diachronic analysis include two late-phase colonial sites (Metini Village and CA-SON-174) and four previously studied indigenous sites that date to late precolonial and/or mercantile colonial times: Tomato Patch, CA-SON-670, the North Wall Community, and the Native Alaskan Village 
Table 1. List of Fort Ross Archaeological Sites and Relevant Dates.

\begin{tabular}{|c|c|c|}
\hline Site & Description & $\begin{array}{c}\text { Chronology of Archaeological } \\
\text { Assemblage }\end{array}$ \\
\hline Metini Village (CA-SON-175) & Kashaya village & 1840s-1860s: main period of occupation \\
\hline $\begin{array}{l}\text { Native Alaskan Village } \\
\quad(\mathrm{CA}-\mathrm{SON}-1897 / \mathrm{H})\end{array}$ & $\begin{array}{l}\text { Multiethnic housing for native Alaskan } \\
\text { workers (men, women) and native } \\
\text { Californian women }\end{array}$ & 1820s-1830s: main period of occupation \\
\hline CA-SON-174 & Kashaya village & 1840s-1860s: main period of occupation \\
\hline Tomato Patch & Kashaya village & Precolonial-1841 \\
\hline Archy Camp (CA-SON-670) & Kashaya village & Precolonial-1841 \\
\hline North Wall Community & $\begin{array}{l}\text { Multiethnic housing for native } \\
\text { Californian laborers and single } \\
\text { women, Creoles, and Russians }\end{array}$ & 1810s-1830s: main period of occupation \\
\hline
\end{tabular}

site (NAVS). The locations of the six sites are illustrated in Figure 1, while Table 1 and Supplemental Text 3 provide more information on the sites.

The use of native oral traditions, archival documents, and the comparison of the archaeological assemblages from Metini Village and CA-SON174 with the four earlier colonial-age indigenous sites indicates both change and continuity in the lifeways and cultural practices of the Kashaya Pomo who worked for the Benitz Ranch. Many of the transformations speak to the significant longterm impacts of colonialism upon the Kashaya people as they became increasingly dependent on a wage-based market economy. It appears that Kashaya entanglements with the RAC provided them with a suite of experiences and some level of expertise in serving as agrarian laborers for settler ranches. Similar to their responses to firstwave colonists, the Kashaya used their values and principles to mediate their relations with settler colonists. Our analysis indicates that they continued to maintain core cultural practices, sustained the use of their broader indigenous landscape, and developed a broader tribal organization, which involved the construction of a dance house that periodically pulled together the wider Kashaya community through communal gatherings involving rituals, dances, singing, and feasts.

\section{Perseverance of Core Cultural Practices}

The analysis of Metini Village and CA-SON174 indicates that the Kashaya Pomo continued to exert their agency by maintaining basic cultural practices while living and working at the Benitz Ranch. Yet significant cultural transformations took place as the Kashaya enacted their cultural practices in a different historical and colonial context. Kashaya entanglements with settler colonists in the 1840s-1860s specifically resulted in significant changes revolving around technology, menu, dress, and the organization of space.

Technology. Chipped-stone artifacts are a major constituent of the artifact assemblages for both Metini Village and CA-SON-174. The reduction of cores into core tools (bifaces) and flakes via percussion methods is evident in the debitage recovered, including shatter and various types of flakes. A significant change that took place was the increasing use of glass in the production of flaked artifacts. The ratio of worked-glass artifacts to chipped-stone artifacts is 1.9 at Metini Village and 0.6 at CA-SON-174, which is considerably greater than those at earlier colonial-age sites, whose ratios range from 0.001 to 0.07 (Table 2). The Kashaya refined their chipped stone technologies, honed over many centuries, to work glass into various kinds of expedient flake tools previously made from obsidian and chert. Much of this glass originated from dark green, heavy-duty alcohol bottles, which appear to have been readily obtainable from the Benitz Ranch.

The analysis of the four earlier colonial sites documented high levels of ceramic frag- 
Table 2. Worked-Glass and Chipped-Stone Artifact Counts and Ratios for Fort Ross Archaeological Sites.

\begin{tabular}{lccc}
\hline Site & $\begin{array}{c}\text { Ratio of Worked } \\
\text { Glass to Chipped Stone }\end{array}$ & $\begin{array}{c}\text { Worked } \\
\text { Glass }(n)\end{array}$ & $\begin{array}{r}\text { Chipped } \\
\text { Stone }(n)\end{array}$ \\
\hline Metini Village (CA-SON-175) & 1.90 & 232 & 123 \\
North Wall Community (CA-SON-190) & & & 1,303 \\
$\quad$ Ballard 1995 & 0.06 & 191 & 2,736 \\
Gonzalez 2011 & 0.07 & 647 & 1,085 \\
CA-SON-174 & 0.60 & 2 & 1,533 \\
Archy Camp (CA-SON-670) & 0.001 & 10 & 6,339 \\
Tomato Patch & 0.001 & 73 & 1,486 \\
Native Alaskan Village (CA-SON-1897/H) & 0.05 & & \\
\hline
\end{tabular}

mentation, modest numbers of ceramic artifacts, and evidence that some sherds had been intentionally worked (Lightfoot and Gonzalez 2018). Our interpretation is that local natives may have been recycling colorful or distinctive ceramic fragments from Russian dumps and refurbishing them as gaming pieces, pendants, or charms. While the Metini Village ceramic assemblage is also highly fragmented, few of the sherds exhibit evidence of working, and the largest percentage are white ironstones, most of which are undecorated. We believe that refined earthenware ironstone plates, bowls, and cups may then have been provided by Benitz and used by the native residents for serving or consuming food and liquids.

Menu. Foodway practices exhibit both change and persistence in the 1840s-1860s. Rich shellfish assemblages containing California mussel (Mytilus californicus), chitons (Katharina tunicata, Cryptochiton stelleri), limpets (Acmaea sp., Notoacema sp., Collisella sp.), turban snails (Tegula funebralis, T. brunnea), abalone (Haliotis sp.), and barnacles (Balanus sp.) are common at all six sites. Native people residing in various colonial settings associated with the Russian colony and Benitz Ranch regularly collected shellfish from nearby rocky intertidal habitats. A major change found at both Metini Village and CA-SON-174 is the increase in meat provided by ranch animals, particularly domestic cow (Bos taurus) and goat/sheep (Capra/Ovis sp.). Whereas the primary terrestrial fauna recovered from earlier colonial sites include black-tailed deer (Odocoileus hemionus) and other deer-sized game along with various species of smaller game and some cattle and pig (Sus scrofa), the fauna at Metini Village and CA-SON-174 are dominated by cow, followed by black-tailed deer, sheep/goat, and small game (Farris 1983; Newquist 2002:54-56; Wake and Lightfoot 2018).

Marine mammals and fish are rare in the six sites, with the exception of NAVS, where native Alaskan marine mammal hunters resided with Kashaya Pomo and native Alaskan women. The NAVS assemblage also exhibits the most diverse suite of birds, including many inshore and pelagic waterbirds. Tomato Patch and the North Wall Community include swans/geese/ducks (Anatidae), common murre (Uria aalge), cormorant (Phalacrocorax sp.), owls (Strigidae), gull (Larus sp.), and chicken (Gallus gallus [Ballard 1995:210; Martinez 1998:149-150]), while bird remains either were not recovered or consist of a few unidentifiable elements at Metini Village, CA-SON-174, and Archy Camp (Fenner 2002:26; Newquist 2002:55). Flotation analyses have only been completed for Metini Village. The results indicate that people processed both domesticated and wild plant foods, including wheat (Triticum spp.), barley (Hordeum vulgare cf.), California poppy (Eschscholzia sp. cf.), bluegrass (Poa sp. cf.), knotweed/dock (Polygonum/Rumex sp.), and California bay (Umbellularia californica), along with specimens from the pink (Caryophyllaceae cf.), legume (Fabaceae), grass (Poaceae), rose (Rosaceae cf.), and nightshade (Solanaceae cf.) families and some pea (Pisum sativum) remains (Lightfoot and Gonzalez 2018).

Our findings corroborate archival sources that indicate native workers at Benitz Ranch were 
paid with food rations, including wheat, barley, peas, beef, and mutton, raised on the ranch. The diverse range of beef meat cuts suggests that live cattle were given to the Kashaya Pomo workers, who then slaughtered, processed, cooked, and consumed the meat at the village site.

While there was an increasing dependence on domesticated species in the 1840s-1860s, there is little evidence that they were processed or consumed differently than other wild foods. A significant component of the lithic assemblage of Metini Village consists of fire-cracked rocks and ground-stone tools, which suggest that meat dishes continued to be cooked in underground ovens, mixed with gruel using the hot rocks method, or placed on embers in hearths. Wood charcoal from local pine (Pinus sp.), willow (Salix sp. cf.), coast redwood (Sequoia sempervirens), and California bay (U. californica) provided fuel for the hearths and ovens, and the recovery of burned daub at Metini Village may be evidence of earth ovens or some other features that were thermally altered. Similarly, the wheat and barley found at Metini Village were probably prepared and cooked in a similar fashion as other wild seeds, which were processed by parching in baskets and grinding into a fine meal using hopper mortars (Lightfoot and Gonzalez 2018).

Dress. The comparison of Metini Village and CA-SON-174 with the earlier colonial sites suggests that new forms of Western dress may have become more common among the indigenous workers in the 1840s-1860s. The increasing number of glass, ceramic (Prosser), brass, and other metal buttons and an iron snap fastener suggest increasing access to work jeans and shirts. The glass beads recovered at Metini Village include later types (red-on-white, Bohemian cut beads, at least one green-colored uranium bead) and a somewhat different color profile than those found at earlier sites (Supplemental Figure 1 and Supplemental Text 5).

Spatial Organization. The spatial layouts of Metini Village and CA-SON-174 indicate both continuities and transformations compared with earlier indigenous sites. The increasing occurrence of glass windowpane pieces as well as wrought and cut nails suggests that Western building techniques may have been employed in some of the residential architecture. While new forms of architectural innovations may have been incorporated at Metini Village, the builders employed Kashaya principles for laying out space, which have deep roots in the region.

Fieldwork at Metini Village revealed a large pit feature and an extensive midden area containing lithic, glass, ceramic, and metal objects, along with faunal specimens (shellfish, fish, mammals) and floral remains. Archival and archaeological research suggests that the large pit feature was a small dance house centrally located in the village (see Lightfoot and Gonzalez 2018). The midden area consists of a 10- to 15-m-wide deposit east of the pit feature, which extends about $60 \mathrm{~m}$ along the terrace edge and then continues down the terrace slope about $20 \mathrm{~m}$ or so to the east toward Fort Ross Creek (Figure 2). This is where much of the residue from tool production and food processing, cooking, and consumption is found. A "clean zone" beyond the midden deposit and pit feature was almost totally devoid of artifacts and faunal remains. The Kashaya appear to have kept this area intentionally clean.

We believe that a major transformation took place in how people demarcated clean areas on precolonial and early colonial-aged sites compared with later historical indigenous villages. The spatial analysis of earlier sites suggests that clean areas were maintained in and around residential architecture in contrast to nearby garbage dumps. By the 1850s and 1860s, it appears that extensive areas kept clear of debris now demarcated special places for holding ceremonies and large communal assemblies. As suggested by contemporary Kashaya scholars who worked on the project, the "clean zone" at Metini Village may signify a sacred area associated with the dance house and adjacent outdoor space for hosting large gatherings of people.

The spatial layout of CA-SON-174 shows that three large surface depressions were placed along the southern perimeter of the site, some distance away from the midden deposits. While the function of these features is unclear, they may have served as sweat houses or some other special kind of public architectural features. Our field investigation also found that the area 


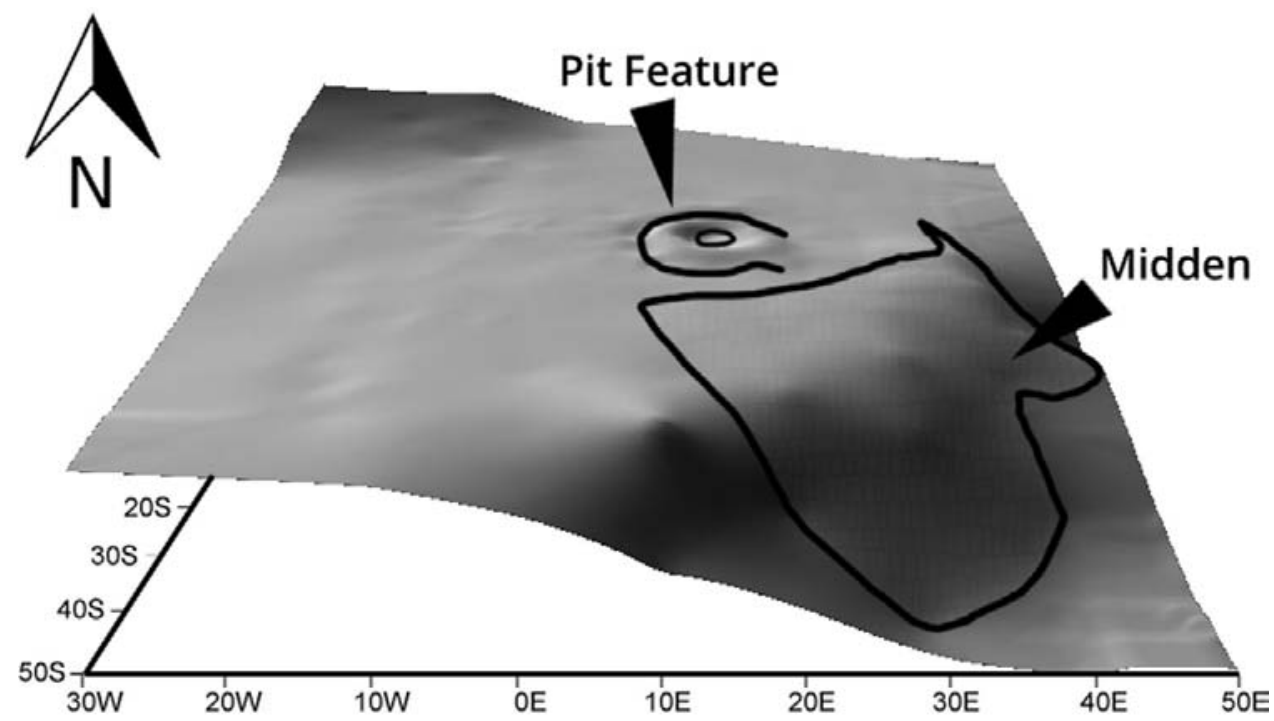

Figure 2. Spatial layout of Metini Village (CA-SON-175), including the pit feature and the midden area. The grid is marked at $10 \mathrm{~m}$ increments.

around these structures was kept relatively clean (Lightfoot et al. 1991:69-76).

\section{Maintaining an Indigenous Hinterland}

Schneider has identified "indigenous hinterlands," spaces situated away from colonial establishments, as significant landscapes where native people "upheld deep-seated traditions of mobility, affirmed a sense of place, and enacted creative responses to external threat as they had done long before the arrival of Europeans" (2015:705). It is argued elsewhere that the ability of the Kashaya to move back and forth between the colonial world and their indigenous homelands-which Kashaya oral histories refer to as the "forest depths"-may have been a crucial factor in the perseverance of their worldviews, values, and traditions during their encounters with the RAC (Lightfoot 2005:207). There is some evidence that the residents of Metini Village and CA-SON174 retained strong connections to indigenous people and resources in the broader hinterland of the Benitz Ranch through hunting and gathering, as well as by the direct procurement or exchange of nonlocal goods. As previously noted, deer remains from outlying habitats persisted as a common constituent of the faunal assemblage. Metini residents also harvested a diverse range of indigenous plants from nearby and distant habitats. And while the overall trend was that dark glass from alcohol bottles replaced chippedstone materials, obsidian from Annadel and Napa Valley sources - situated many kilometers into the interior-continued to be obtained by residents from both villages, most probably through social interactions with outlying groups.

Our case study also exemplifies one of the challenges outlined above in undertaking studies of sustained colonialism: there has been no concerted effort to detect indigenous remains in the indigenous hinterland that may be contemporaneous with late nineteenth-century settler colonialism. While Kashaya oral traditions identify some of these places (see Oswalt 1964), they are currently not accessible for study, or the specific locations remain unknown. Consequently, examining Kashaya technology, menu, dress, and spatial organization beyond the sites associated with the Benitz Ranch is not possible now. Future collaborative work with the tribe may shed significant light on these outlying places.

\section{The Creation of a Tribal Organization}

The Kashaya continued the process of developing a broader tribal organization in the 1840s1860s. The 1848 census records 161 Indians residing at the Benitz Ranch (Ross Census 1848). 
They included 4 chiefs and their wives, 47 couples, 12 single adults, and 47 children. The leaders' names indicate that the practice of designating one of the leaders as "toyon" persisted in the post-Russian period. The census information also suggests that the previous process of aggregating together multiple small polities, each with its own chief, into a more expansive Kashaya tribal identity and settlement system continued to take place in later historical times.

The chief designated as toyon served as the primary leader for the emerging Kashaya tribe, and he appears to have worked with the other chiefs for the greater good of the community. This point is exemplified during confrontations with hostile settler colonists who periodically ransacked Indian villages in the Kashaya Pomo and Coast Miwok territories to capture Indians for use as laborers. One such raid took place at Benitz Ranch in 1845 when the owner was absent. The marauders broke into Benitz's home, raped some of the indigenous women working there, and plundered the "Indian Village" (Kennedy 1955:78). The raiding party captured two of the Indian "captains or chiefs," who were able to outfox the marauders by telling them that they would lead them to the rest of the Indian population who remained hidden. The two Kashaya men then escaped and saved the majority of the community from capture (Franklin 2018; Kennedy 1955:78-79). That two chiefs worked together to thwart the malicious efforts of the raiders reveals how the broader tribal organization had definite advantages for engaging with settler colonists.

We argue that a crucial component in the development of the broader Kashaya tribe was the emergence of the dance house at Metini Village. While semisubterranean dance or assembly houses are well documented by ethnographers working among the Pomo people of northern California (Kniffen 1939:362; Stewart 1943:50), their evolution in precolonial times is not well documented in the archaeological literature. Both Stewart and Kniffen suggested that large pit features tended to be associated with important villages, but the function of these features remains unclear, as they may have served as dance houses, sweat houses, or houses of influential leaders.
While details of Kashaya villages, including residential architecture and sweat houses, were described by colonial visitors in Russian times, no such observations are known for the large dance houses (see Kennedy 1955:11). These structures would have been the largest and most visible architectural forms in Indian settlements, so it is puzzling that they are absent in the ethnohistorical literature. They may have been built and used in outlying Kashaya villages in the "forest depths," well beyond the Ross Settlement and not readily accessible to the RAC and colonial visitors. Kennedy (1955:11) cites ethnographic accounts of Marie James, a Kashaya elder, who recalled that brush shelters were used for major dances and ceremonies until the first dance house was constructed in the area when she was about eight years old (ca. 1857).

While it is not clear whether the dance house at Metini Village was a new building innovation or the re-creation of an architectural form that had ancient roots among the Kashaya Pomo that had been kept hidden from the first-wave colonists, its public emergence in the 1850s and 1860s represented a significant symbolic statement for the emerging Kashaya tribal entity. As Kashaya elders and scholars emphasize, the dance house not only served as a significant place for undertaking ceremonies, dances, feasts, and curing rituals; it also performed an important integrative role in drawing together the greater Kashaya Pomo community from across the region for periodic communal gatherings. It marked a tangible place in the Kashaya homeland where the broader tribal groups could gather, interact, and contemplate the future. During a time in which native Californians were being forcibly removed from their homelands and denied political recognition by the US government and were under threat of violence, these gatherings are a powerful indicator of the Kashaya's refusal of settler colonialism and a critical part of their survivance.

\section{Discussion}

A significant finding in our study of sustained colonialism in the Kashaya Pomo homeland is how both change and continuity took place simultaneously as native people interacted with 
foreigners over the course of a half century. This observation is not unique to the Kashaya Pomo. Recent advances in the archaeology of colonialism highlight how cultural change and transformation often take place side by side as two sides of the same process when indigenous people negotiate with others (Panich 2013; Silliman 2009:211; Stahl 2012). Archaeologists are now examining long-term trajectories of indigenous entanglements with colonial interlopers that involved the continual interplay of change and continuity over the course of many decades, what Panich (2013) refers to as the archaeology of persistence. In examining colonialism as an extended marathon of cultural modification, negotiation, and resistance, what emerges is a more nuanced view of the survivance of native communities. According to Doerfler,

Survivance is an active word that goes beyond mere physical survival to include the "tease of tradition." ... In this way, traditions are incorporated and adapted to contemporary issues, but this change and adaptation does not mean American Indians have "lost" anything; rather they are an integral part of survivance [2010:191].

Framed thusly, the multiple entanglements, outcomes, and routes that indigenous communities navigated are part of a rich tableau, one in which native peoples strategically deployed, refused, and infused material culture with new meanings as they grappled with colonialism. Change, in this context, is a necessary product of survivance-just as cultural practices were and remain vital community resources.

Our case study demonstrates that significant cultural transformations took place in the menu, technology, dress, and spatial organization of the Kashaya Pomo from the early 1800 s to the 1860 s. Yet we argue that these changes were highly structured and built upon the cultural values and worldview of the Kashaya people as they accrued experience and knowledge in how to negotiate with different colonial enterprises over time. The Kashaya created multiple strategies and responses for negotiating their relationships with colonists. They stressed the maintenance of core cultural practices, sustained connections to a broader indigenous landscape, and ensured con- tinuities in a political organization that retained the authority and power of traditional tribal leaders. During their interactions with first-wave Russian merchants (1812-1841), the employment of these tactics by the Kashaya led to both change and persistence in tool production, foodways, raw materials, settlement patterns, and tribal political organizations.

They then used their experiences and insights from these previous colonial encounters to develop responses to a new wave of settler colonists in the 1840s-1860s. As the Kashaya became increasingly integrated into a market economy, they continued to employ their tribal protocols for working with foreign raw materials and tools, using new foods and dress, and organizing their village space. They also maintained their connections to resources and indigenous people dispersed across the broader indigenous landscape, particularly in outlying "forest depths." Further consolidation of a broader tribal entity was taking place as they constructed a dance house at Metini Village in the 1850s. We believe that these developments marked a significant watershed for the Kashaya Pomo people in their efforts to maintain their Indian community and cultural values in the face of sustained colonialism.

The dance house at Metini Village represents an early manifestation of a religious revitalization movement among the Kashaya Pomo that offered spiritual renewal through the teachings of religious leaders, a philosophy for returning to the basics of native lifeways, and communal assemblies that would bring the entire outlying community together for periodic dances, ceremonies, and feasts. Kennedy (1955:89) discussed the critical role that religious practices played in keeping the Kashaya Pomo together as a viable Indian community in late historical times. This was a period in which the community was forced by later settler colonists to move from Benitz Ranch to Haupt's Ranch and other outlying locations in the 1870s and then finally relocated to Stewarts Point Rancheria, which was purchased as trust land in 1914 (see also Oswalt 1964:4).

Both continuity and transformation are evident in new forms of religious architecture and practices, which were outgrowths of earlier 
developments at Metini Village. Liebmann's $(2008,2012 b)$ archaeological investigation of the Pueblo Revolt in the American Southwest highlights how revitalization movements are often associated with a florescence of creative materiality rooted in the past. Innovations took place in the Kashaya homeland as religious leaders transformed the semisubterranean earth-covered dance house architectural style at Metini Village into large aboveground, redwood-planked round houses in the late 1800s and early 1900s, which could hold about 150 people. These later aboveground structures were associated with spiritual revivals, most notably the emergence of the dreamer or Bole-Maru religious practices that derived from the 1870s Earth Lodge cult of the Ghost Dance movement, along with ancient forms of Kashaya belief. These religious practices, built upon the foundations of earlier practices at Metini Village and other more ancient sites, involved women prophets, such as the renowned Annie Jarvis and Essie Parrish, who were crucial forces in keeping the Kashaya Pomo together as a united people during the difficult times of later settler colonization (see Kennedy 1955:125-135; Oswalt 1964:4-6).

\section{Conclusion}

In this article we advocate for the study of sustained colonialism, for an examination of how native peoples negotiated multiple waves of foreigners over many decades of mercantile and settler entanglements. While archaeologists are well versed in the study of indigenous encounters with first-wave colonists, there is a dearth of research involving native entanglements with later colonists, particularly settler colonists. The reasons for this trend are complex and multifaceted. They relate to the difficulties of detecting and dating later indigenous archaeological remains, as well as a common precedent to terminate studies of indigenous/colonial interactions with the rise of the modern US nation in the nineteenth and twentieth centuries. The trope of the vanishing Indian, most notably associated with the advent of settler colonialism, has certainly influenced the archaeological protocols employed in determining what, who, and the time periods we study.
We believe that the best way to address these challenges is to create collaborative research programs with tribal partners that are devoted to the detection, dating, and study of late historical indigenous archaeological remains. Not only will this provide a wealth of information for examining how native people confronted multiple waves of colonizers who trespassed on their lands, but it will serve the interests of tribal partners who often need to demonstrate continued occupation of their territories for various legal purposes. Collaborative investigations of the recent past and histories of tribal persistence are particularly salient for communities such as the Kashaya. By providing ample details concerning native peoples' survivance, even during the dark years of settler colonialism, studies of sustained colonialism are crucial in refuting terminal narratives about Indian extinctions, for recognizing tribal sovereignty on their lands, and for transforming public perceptions about the persistence of indigenous populations. They also, importantly, allow communities such as the Kashaya to remember together how they have not just persisted but thrived in the face of seemingly insurmountable obstacles and violence.

We conclude with three observations from our case study of sustained colonialism in the homeland of the Kashaya Pomo in northern California. First, it is possible to incorporate previous archaeological investigations of firstwave colonists, which have been conducted in many places across North America, into more protracted diachronic frameworks for examining the long-term effects of colonial interactions. Comparative analyses can be implemented using a suite of indigenous sites that provide multiple temporal points in a time line that spans late precolonial, early colonial, and later colonial times to the present.

Second, our case study shows how the experiences and insights that indigenous people accrued during their interactions with first-wave colonists were redeployed in negotiating with later colonists. We observed multiple strategies that the Kashaya devised in dealing with Russian merchants from 1812 to 1841 , including the maintenance of core cultural practices, sustaining a broader indigenous landscape, and the creation of a more extensive indigenous political 
entity. They then employed variations of these strategies in their entanglements with later settler colonists in the 1840s-1860s. In retrospect, it is significant how little long-term influence some of these colonial interactions had on the Kashaya. This is exemplified by the close relationships that took place between native Californian women and native Alaskan men in interethnic households at NAVS. While Indian women participated extensively in the preparation and consumption of sea mammals and fish at NAVS, there is almost no evidence that these practices were transferred to their indigenous homelands or enacted in the later colonial setting at Benitz Ranch.

Finally, the long-term outcomes of the above strategies led to both change and continuity in the lifeways, political organization, and religious practices of the Kashaya Pomo. We discussed how persistence (both transformation and continuity) took place in their technology, menu, dress, and spatial organization of villages during the period of 1812 to the $1860 \mathrm{~s}$. The most significant developments involved sustaining a broader indigenous landscape, the consolidation of multiple polities into an integrated tribal organization, and the construction of a dance house at Metini Village. These developments represented a major turning point in the survival of the Kashaya as a people. They also set the stage for later entanglements with settler colonists into the twentieth century that involved a unified Kashaya identity, the incorporation of an extensive population base, and a revitalization movement involving the rise of powerful women religious leaders. Indeed, these leaders-Annie Jarvis and Essie Parrish-are recognized today as crucial catalysts in keeping the tribe together. They were major contributors to tribal resiliency and survivance by advocating for the continuation of Kashaya cultural values, Kashaya cultural and religious practices, and the speaking of the Kashaya language.

Acknowledgments. This research would not have been possible without the assistance and support of many people from the Kashaya Pomo and California State parks. Permission to publish this article was granted by the Kashia Band of Pomo Indians and Chairman Emeritus Reno Franklin. The work was generously funded with a grant from the National Science Foundation (SBR-9806901). A full list of acknowledgments is listed in Lightfoot and Gonzalez 2018. We appreciate greatly the excellent editorial support of Robert Kelly and the constructive comments of three reviewers.

Data Availability Statement. The data employed in this article are available in the appendixes in Lightfoot and Gonzalez 2018. The field notes and materials from CASON-175 and CA-SON-174 are curated in the California State Archaeological Collections and Research Facility in McClellan, California.

Supplemental Materials. For supplementary material accompanying this article, visit https://doi.org/10.1017/aaq. 2018.17.

Supplemental Text 1. Forest Depths.

Supplemental Text 2. Methods for Studying Sustained Colonialism.

Supplemental Text 3. Background on Sites Examined. Supplemental Text 4. Supplemental References Cited. Supplemental Text 5. Supplemental Figure 1 Caption.

Supplemental Figure 1. (a-g) Metini Village (CA-SON175) glass beads.

\section{References Cited}

Atalay, Sonya

2006 No Sense of the Struggle: Creating a Context for Survivance at the NMAI. American Indian Quarterly 30:597-618.

Ballard, Hannah S.

1995 Searching for Metini: Synthesis and Analysis of Unreported Archaeological Collections from Fort Ross State Historic Park, California. Senior Honors thesis, Department of Anthropology, University of California, Berkeley.

Cipolla, Craig N.

2013 Becoming Brothertown: Native American Ethnogenesis and Endurance in the Modern World. University of Arizona Press, Tucson.

Coronil, Fernando

2007 After Empire: Reflections on Imperialism from the Americas. In Imperial Formations, edited by Laura A. Stoler, Carole McGranahan, and Peter C. Perdue, pp. 241-271. SAR Press, Santa Fe, New Mexico.

Deagan, Kathleen

2010 Strategies of Adjustment: Spanish Defense of Circum-Caribbean Colonies, 1493-1600. In First Fort: Essays on the Archaeology of Proto-Colonial Fortifications, edited by Eric Klingelhöfer, pp. 17-39. History of Warfare, Vol. 60. Brill Academic Publishers, Boston.

Doerfler, Jill

2010 Postindian Survivance: Gerald Vizenor and Kimberly Blaeser. In Gerald Vizenor, edited by Deborah L. Madsen and Robert A. Lee, pp. 186-207. University of New Mexico Press, Albuquerque.

Farris, Glenn J.

1983 Archaeological Excavations Related to the Construction of the Fort Ross Visitor's Center, Fort Ross State Historic Park, Sonoma County, California. Manuscript on file, Cultural Resource Support Unit, Department of Parks and Recreation, Sacramento, California.

2012 So Far from Home: Russians in Early California. Heyday, Berkeley, California. 
Fenner, Morgan

2002 An Analysis of the Occupants of CA-SON-670/H at Fort Ross State Historic Park. Senior Honors thesis, Department of Anthropology, University of California, Berkeley.

Franklin, Reno Keoni

2018 Forward to Volume. In Metini Village: An Archaeological Study of Sustained Colonialism, Kent G. Lightfoot and Sara L. Gonzalez, pp. xv-xvi. The Archaeology and Ethnohistory of Fort Ross, California, Vol. 3. Contributions of the University of California Archaeological Research Facility, No. 69. Archaeological Research Facility, Berkeley, California.

Gonzalez, Sara L.

2011 Creating Trails from Tradition: The Kashaya Pomo Interpretive Trail at Fort Ross State Historic Park. PhD dissertation, Department of Anthropology, University of California, Berkeley.

Johnston, Anna, and Alan Lawson

2000 Settler Colonies. In A Companion to Post-Colonial Studies, edited by Henry Schwarz and Sangeeta Ray, pp. 360-376. Blackwell Publishers, Oxford.

Kennedy, Mary Jean

1955 Culture Contact and Acculturation of the Southwestern Pomo. PhD dissertation, Department of Anthropology, University of California, Berkeley.

Kniffen, Fred

1939 Pomo Geography. University of California Publications in American Archaeology and Ethnology 36(6):353-400. University of California Press, Berkeley.

Liebmann, Matthew

2008 The Innovative Materiality of Revitalization Movements: Lessons from the Pueblo Revolt of 1860. American Anthropologist 110:360-372.

2012a The Rest Is History: Devaluing the Recent Past in the Archaeology of the Pueblo Southwest. In Decolonizing Indigenous Histories: Exploring Prehistoric/Colonial Transitions in Archaeology, edited by Maxine Oland, Siobhan M. Hart, and Liam Frink, pp. 19-44. University of Arizona Press, Tucson.

2012b Revolt: An Archaeological History of Pueblo Resistance and Revitalization in 17th Century New Mexico. University of Arizona Press, Tucson.

Lightfoot, Kent G.

2005 Indians, Missionaries, and Merchants: The Legacy of Colonial Encounters on the California Frontiers. University of California Press, Berkeley.

2006 Missions, Furs, Gold and Manifest Destiny: Rethinking an Archaeology of Colonialism for Western North America. In Historical Archaeology, edited by Martin Hall and Stephen W. Silliman, pp. 272-292. Blackwell Publishing, Malden, Massachusetts.

Lightfoot, Kent G., and Sara L. Gonzalez

2018 Metini Village: An Archaeological Study of Sustained Colonialism. The Archaeology and Ethnohistory of Fort Ross, California, Vol. 3. Contributions of the University of California Archaeological Research Facility, No. 69. Archaeological Research Facility, Berkeley, California.

Lightfoot, Kent G., Antoinette Martinez, and Ann Schiff

1998 Daily Practice and Material Culture in Pluralistic Social Settings: An Archaeological Study of Culture Change and Persistence from Fort Ross, California. American Antiquity 63:199-222.
Lightfoot, Kent G., Lee M. Panich, Tsim D. Schneider, and Sara L. Gonzalez

2013 European Colonialism and the Anthropocene: A View from the Pacific Coast of North America. Anthropocene 4:101-115.

Lightfoot, Kent G., Ann M. Schiff, and Thomas A. Wake

1997 The Native Alaskan Neighborhood: A Multiethnic Community at Colony Ross. The Archaeology and Ethnohistory of Fort Ross, California, Vol. 2. Contributions of the University of California Archaeological Research Facility No. 55. Archaeological Research Facility, Berkeley, California.

Lightfoot, Kent G., Thomas A. Wake, and Ann M. Schiff 1991 Introduction. The Archaeology and Ethnohistory of Fort Ross, California, Vol. 1. Contributions of the University of California Archaeological Research Facility No. 49. Archaeological Research Facility, Berkeley, California.

Lindsay, Brendan C.

2012 Murder State: California Native American Genocide 1846-1873. University of Nebraska Press, Lincoln.

Madley, Benjamin

2016 An American Genocide: The United States and the California Indian Catastrophe. Yale University Press, New Haven, Connecticut.

Martinez, Antoinette

1998 An Archaeological Study of Change and Continuity in the Material Remains, Practices and Cultural Identities of Native California Women in a Nineteenth Century Pluralistic Context. PhD dissertation, Department of Anthropology, University of California, Berkeley.

Mitchell, Mark D., and Laura L Scheiber

2010 Crossing Divides: Archaeology as Long-Term History. In Across a Great Divide: Continuity and Change in Native North American Societies, 1400 1900, edited by Laura L. Scheiber and Mark D. Mitchell, pp. 1-22. University of Arizona Press, Tucson.

Mrozowski, Stephen A., Holly Herbster, David Brown, and Katherine L. Priddy

2009 Magunkaquog Materiality, Federal Recognition, and the Search for Deeper Meaning. International Journal of Historical Archaeology 13:430-463.

Murray, Tim

2004 The Archaeology of Contact in Settler Societies. In The Archaeology of Contact in Settler Societies, edited by Tim Murray, pp. 1-16. Cambridge University Press, Cambridge.

Nassaney, Michael

2015 The Archaeology of the North American Fur Trade. University Press of Florida, Gainesville.

Newquist, Ingrid

2002 Kashaya in Post-Russian Times: Analysis of Archaeological Materials from a Multi Occupation Site at Fort Ross, California. Senior Honors thesis, Department of Anthropology, University of California, Berkeley.

Oswalt, Robert L.

1964 Kashaya Texts. Publications in Linguistics No. 36. University of California, Berkeley.

Panich, Lee M.

2013 Archaeologies of Persistence: Reconsidering the Legacies of Colonialism in Native North America. American Antiquity 78:105-122. 
Ross Census

1848 Presidio Ross. January 8th 1848. Lists of Indians at Present Time. Vallejo Papers, Vol. 3, No. 326. Manuscript on file, Bancroft Library, University of California, Berkeley.

Rubertone, Patricia E.

2012 Archaeologies of Colonialism in Unexpected Times and Unexpected Places. In Decolonizing Indigenous Histories: Exploring Prehistoric/Colonial Transitions in Archaeology, edited by Maxine Oland, Siobhan M. Hart, and Liam Frink, pp. 267-281. University of Arizona Press, Tucson.

Russell, Lynette

2001 Introduction. In Colonial Frontiers: IndigenousEuropean Encounters in Settler Colonies, edited by Lynette Russell, pp. 1-15. Manchester University Press, Manchester, United Kingdom.

Schneider, Tsim D.

2015 Placing Refuge and the Archaeology of Indigenous Hinterlands in Colonial California. American Antiquity 80:695-713.

Silliman, Stephen W.

2009 Change and Continuity, Practice and Memory: Native American Persistence in Colonial New England. American Antiquity 74:211-230.

2012 Between the Longue Durée and the Short Purée: Postcolonial Archaeologies of Indigenous History in Colonial North America. In Decolonizing Indigenous Histories: Exploring Prehistoric/Colonial Transitions in Archaeology, edited by Maxine Oland, Siobhan M. Hart, and Liam Frink, pp. 113-131. University of Arizona Press, Tucson.

Sleeper-Smith, Susan

2001 Indian Women and French Men: Rethinking Cultural Encounter in the Western Great Lakes. University of Massachusetts Press, Amherst.

Stahl, Ann B.

2012 When Does History Begin? Material Continuity and Change in West Africa. In Decolonizing Indigenous Histories: Exploring Prehistoric/Colonial Transitions in Archaeology, edited by Maxine Oland, Siobhan M. Hart, and Liam Frink, pp. 158-177. University of Arizona Press, Tucson.

Stewart, Omer C.

1943 Notes on Pomo Ethnogeography. University of California Publications in American Archaeology and Ethnology 40(2):29-62.

Stoler, Laura Ann, and Carole McGranahan

2007 Introduction: Refiguring Imperial Terrains. In Imperial Formations, edited by Laura A. Stoler, Carole McGranahan, and Peter C. Perdue, pp. 3-42. SAR Press, Santa Fe, New Mexico.

Tomlin, Kaye

1993 The Caretakers: After the Russian-American Company. Fort Ross Interpretive Association, Fort Ross, California.

Vizenor, Gerald

2008 Survivance: Narratives of Native Presence. University of Nebraska Press, Lincoln.

Wake, Thomas A., and Kent G. Lightfoot

2018 Vertebrate Faunal Remains. In Metini Village: An Archaeological Study of Sustained Colonialism, Kent G. Lightfoot and Sara L. Gonzalez, pp. 89-92. The Archaeology and Ethnohistory of Fort Ross, California, Vol. 3. Contributions of the University of California Archaeological Research Facility, No. 69. Archaeological Research Facility, Berkeley, California.

Wilcox, Michael V.

2010 Marketing Conquest and the Vanishing Indian: An Indigenous Response to Jared Diamond's Guns, Germs, and Steel and Collapse. Journal of Social Archaeology 10:93-117.

Wolfe, Patrick

2006 Settler Colonialism and the Elimination of the Native. Journal of Genocide Research 8:387-409.

Submitted September 7, 2017; Revised February 17, 2018; Accepted February 20, 2018 